\title{
Taking Politics Seriously - but Not Too Seriously
}

\author{
Charles Blattberg \\ (Université de Montréal)
}

\begin{abstract}
It makes one ashamed - that men of our advanced years should turn a thing as serious as this into a game.

Seneca ${ }^{1}$

One of Edward's Mistresses was Jane Shore, who has had a play written about her, but it is a tragedy \& therefore not worth reading.
\end{abstract}

Jane Austen ${ }^{2}$

To Isaiah Berlin, the idea "that all good things must be compatible ... and perhaps even entail one another in a systematic fashion [is] perhaps one of the least plausible beliefs ever entertained by profound and influential thinkers." 3 So says pluralism of monism. The claim is meant to apply as much to personal as to political life, and it has led pluralists to argue that monists overlook the inescapably tragic dimension of both. If, when values conflict, we cannot turn to a systematic theory for guidance, then it seems we have no choice but to compromise and, by compromising, diminish what we believe to be good. That, at least, is what comes from negotiation, which is what pluralists recommend as the chief alternative to the application of monist theories of morality or justice. And they do so even though - or rather because - it means embracing a world that is inherently unsystematic, sometimes tragically so. ${ }^{4}$

One might push this point even further. Monists do not merely fail to give the tragedy of morals or politics its due; some can even be accused of treating them frivolously, as if they were

\footnotetext{
*A chapter from Towards One, As Many (forthcoming). A shorter version appears as "Taking Politics Seriously," Philosophy 94, no. 2 (April 2019): 271-94. Thanks to Daniel A. Bell, Yves Couture, Andrew Lister, William Clare Roberts, and Daniel Weinstock for comments.

${ }^{1}$ Letters from a Stoic: Epistulae Morales Ad Lucilium, trans. Robin Campbell (Harmondsworth: Penguin, 1969), p. 97.

${ }^{2}$ The History of England (London: Penguin, 1995 [1791]), p. 39.

${ }^{3}$ Berlin, "From Hope and Fear Set Free," in Liberty: Incorporating Four Essays on Liberty, ed. Henry Hardy (Oxford: Oxford University Press, 2002), pp. 278-79.

${ }^{4}$ See, for example, Berlin, "Political Ideas in the Twentieth Century," in Liberty, esp. p. 64; Bernard Williams, "Politics and Moral Character," in Stuart Hampshire, ed., Public and Private Morality (Cambridge: Cambridge University Press, 1978); and Stuart Hampshire, Innocence and Experience (London: Allen Lane, The Penguin Press, 1989), esp. pp. 170-77.
} 
like games. Consider John Rawls' vision of the "well-ordered society." To Rawls: "In much the same way that players have the shared end to execute a good and fair play of the game, so the members of a well-ordered society have the common aim of cooperating together to realize their own and another's nature in ways allowed by the principles of justice."5

The principles in question are those of Rawls' theory of justice and, just like the rules of a formal game, they are supposed to be systematically unified. This comes from meeting three requirements. First, the principles have a lexical priority, which means that they are not to be weighed against each other. ${ }^{6}$ Second, when the various liberties asserted by the first principle are to be balanced, we may only do so by assessing them as a whole, "as one system." So much as with utility in utilitarianism, there's no sense in which liberty should be sacrificed to the needs of another value; on the contrary, it may be compromised "only for the sake of liberty itself."7 Finally, the second principle is said to be the product of a lexically ordered and therefore systematic combination of two others: fair equality of opportunity, and a "difference principle" by which inequalities are permitted only when they benefit the people in society who are the worst off. ${ }^{8}$ All this means that, just like a sports referee or umpire, no one charged with applying Rawls' theory should ever be troubled by having to make tragic compromises. For the systematically unified ordering of its principles will, ostensibly, allow them to keep their hands clean. ${ }^{9}$

But am I right to define Rawls' approach as monistic? After all, as he himself came to see, it is relevant to politics alone, and then only in a very specific, "reasonable" sense. Part of what Rawls means by this derives from his famous distinction between "comprehensive" and strictly "political" conceptions. The former is a view of life that - whether monist, pluralist, or something

\footnotetext{
${ }^{5}$ Rawls, A Theory of Justice (Cambridge, MA: Harvard University Press, 1999, rev. ed.), p. 462; see also Political Liberalism (New York: Columbia University Press, 2005, exp. ed.), p. 204. Others refer to chess, camping trips, or swimming races: Nicolas Denyer, "Chess and Life: The Structure of a Moral Code," Proceedings of the Aristotelian Society 82, no. 1 (June 1982): 59-68; G.A. Cohen, Why Not Socialism? (Princeton: Princeton University Press, 2009), chs. 1-2; and Ronald Dworkin, Justice for Hedgehogs (Cambridge, MA: Harvard University Press, 2011), pp. 28789, 309, 371. Cohen, it should be said, identifies himself as a pluralist in his Rescuing Justice and Equality (Cambridge, MA: Harvard University Press, 2008), pp. 4-6; on p. 37 of the later book, however, his position is agnostic between pluralism and the monism that would be realised if, as he hopes, the principles underlying camping trips were fully compatible with each other.

${ }^{6}$ See Rawls, A Theory of Justice, pp. 37-39.

${ }^{7}$ Ibid., pp. 178-79; see also p. 214.

${ }^{8}$ See ibid., § 13-14.

${ }^{9}$ See my “Dirty Hands: The One and the Many," The Monist 101, no. 2 (Apr. 2018): 150-69.
} 
else - tends to be believed as metaphysically true, while the latter is a view of justice that "neither asserts nor denies" the truth of its principles and judgments. Given this agnosticism, political conceptions are understood to be compatible with many different comprehensive views. To which it is often added that since, after all this time, we have yet to achieve any sort of consensus on a comprehensive view, such metaphysical disagreements may very well be insoluble. But while we seem to be unable to reconcile over comprehensive truth, we can still be reasonable and thereby share and uphold a political conception. ${ }^{10}$

That said, Rawls recognizes that not all comprehensive views will be compatible with a given political conception. ${ }^{11}$ Political homes can nevertheless be made for the reasonable ones, which is why he sees his approach as embracing a "reasonable pluralism - as opposed to [the metaphysical doctrine of] pluralism as such." 12 Yet as we've seen, those holding comprehensive views are not supposed to inhabit the political as a mere collection of disparate people - on the contrary, they are to be governed by a single, unified system. They may still disagree over how to conceive of and apply its principles (Rawls admits that not everyone may accept his own way of doing so, which he calls "justice as fairness"), but the point is that such disagreements will be far less divisive than those over, say, morality and, for this reason, they will not threaten well-orderedness. ${ }^{13}$

So it is this, the fact that the principles are supposed to fit together in a fully coherent way, constituting a oneness, that makes me feel justified in describing Rawls' approach as monistic. True, it is only a partial monism, since limited to the political, but it's not as if there is no precedent for this sort of thing. Think of Hume, who was downright sceptical about the prospects of formulating a unified moral theory while simultaneously being quite ambitious in his political theory. Or, stepping back, we might note that while Berlin is a pluralist about the practical world, he is very probably, like Bernard Williams, a monist as regards the natural, since he seems willing to accept that it makes sense for scientists to strive for a unified, "absolute conception" of nature. ${ }^{14}$

\footnotetext{
${ }^{10}$ Rawls, Political Liberalism, pp. 127, 129. Unsurprisingly, Rawls has gone no further than expressing an agnostic position as regards comprehensive views' claims to moral truth, such as when he describes Thomas Nagel's discussion of the "fragmentation of value" as "not implausible." Ibid., p. 57 n. 10.

11 "Any system of social institutions is limited in the values it can admit so that some selection must be made from the full range of moral and political values that might be realized." Ibid., p. 57.

12 Ibid., p. 129.

${ }^{13}$ See ibid., pp. $240 f f$.

${ }^{14}$ On Hume, see Annette Baier, "Doing without Moral Theory?" in Postures of the Mind: Essays on Mind and Morals (Minneapolis: University of Minnesota Press, 1985). And see Berlin, "The Divorce between the Sciences and
} 
The question of philosophical labels aside, it's clear Rawls believes that people can be united politically while remaining fundamentally divided otherwise, much as the players of a game can be said to unite when they agree to conform to the systematically interlocked rules of its rulebook. Now while I'm also wary of pluralism (to me, the best way lies in between it and monism), I find it astounding that Rawls would compare just politics to the playing of a game. Even more astounding is that, though Rawls appears to be using "game" merely for analogy, the reality, as I will argue, is that justice as he conceives of it $i s$ a game.

\section{I}

Why do we consider games frivolous? The simple reason is that, except for those who, say, play professionally, games normally stand apart from our serious, practical concerns. Practical life is (mostly) serious because its values, which form a whole, just matter to us in that way. ${ }^{15}$ And one reason they do so is that the whole cannot be considered unified, since fulfilling practical values often requires contending with disorder. Partly this is because, as Samuel Todes once put it, "our experience is porous to the blind, dark, and worldless forces that we try to domesticate by bringing them into our world so as to make this world habitable and endurable." ${ }^{\prime 6}$ And partly it is because, as pluralists claim, any ordering of that world will always be limited by our inability to unify our values. Hence, once again, Berlin: "The world that we encounter in ordinary experience is one in

the Humanities," in Against the Current: Essays in the History of Ideas, ed. Henry Hardy (Princeton: Princeton University Press, 2013, 2nd ed.); Williams, "Consistency and Realism," in Problems of the Self: Philosophical Papers 1956-1972 (Cambridge: Cambridge University Press, 1973), where he contrasts conflicts of obligations with conflicts of belief; and Williams, Ethics and the Limits of Philosophy (Cambridge, MA: Harvard University Press, 1985), pp. 111-12, 138-40. It is in his Descartes: The Project of Pure Enquiry (Harmondsworth: Penguin, 1978) that Williams coins the expression "absolute conception" and, on p. 248 of that book, he makes clear he's willing to accept its viability only as regards natural science. Descartes himself went all the way, which is why when Roland Hall describes his ontology as a "partial monism," given Descartes' conception of matter but not mind as a unitary substance, it's evident that Hall is using the term "monism" in a strictly numerical sense: "Monism and Pluralism," in Paul Edwards, ed., The Encyclopedia of Philosophy, vol. 5 (New York: Macmillan, 1967), p. 363. Descartes' belief that all matter and mind can be joined into one, thanks to God, means that, in the sense in which I am using the term, his monism is anything but partial: The Principles of Philosophy (1644), part I, art. 60, in Meditations and Other Metaphysical Writings, trans. Desmond M. Clarke (London: Penguin Books, 2003), p. 135.

${ }^{15}$ This holism, it's worth mentioning, is also behind why we consider the things we encounter in our practical lives as real - including, of course, those things that we do not experience directly (for we sense that our visual field, say, continues on behind our backs). See Maurice Merleau-Ponty, "The Film and the New Psychology," in Sense and NonSense, trans. Hubert L. Dreyfus and Patricia Allen Dreyfus (Evanston, IL: Northwestern University Press, 1964), p. 51.

${ }^{16}$ Todes, Body and World (Cambridge, MA: MIT Press, 2001), p. 58. 
which we are faced with choices between ends equally ultimate, and claims equally absolute, the realisation of some of which must inevitably involve the sacrifice of others." 17

So we can see why, in order to play a game, we need to step out of - some would say "leap from" - the practical. ${ }^{18}$ Games stand apart, that is, because they are independent from practical life as a whole, and because (at least when it comes to formal games) they are fundamentally ordered in a way that the practical is not. Of course, the degree of this apartness varies; games in antiquity, for instance, were seen as much less autonomous activities. The ancient Greeks never affirmed anything like the division between competitive sport and practical life that we, or at least most of us, do today. ${ }^{19}$ In fact, some virtually collapsed the two altogether. It's because Homer saw war as much like athletics that he used the term "grievous" to refer to both battles and sports. ${ }^{20}$ And while Plato obviously preferred philosophical over military struggles, he also seems to have thought of at least the former as a kind of game. ${ }^{21}$ Not that everyone can play it; still, everyone should spend their lives playing "the noblest possible games" since, as Plato has his Athenian Stranger declare,

I assert that what is serious should be treated seriously, and what is not serious should not, and that by nature god is worthy of a complete, blessed seriousness, but that what is human, as we said earlier, has been devised as a certain plaything of god, and that this is really the best thing about it. ${ }^{22}$

\footnotetext{
${ }^{17}$ Berlin, "Two Concepts of Liberty," in Liberty, pp. 213-14.

${ }^{18}$ See Erik H. Erikson, Toys and Reasons: Stages in the Ritualization of Experience (New York: Norton, 1977), p. 17.

${ }^{19}$ On their attitudes, see Michael B. Poliakoff, Combat Sports in the Ancient World: Competition, Violence, and Culture (New Haven, CN: Yale University Press, 1987), ch. 6; and Georgio Agamben, "Note sur la guerre, le jeu et l'ennemi," in Stasis: La guerre civile comme paradigme politique, trans. Joël Gayraud, pp. 300-15, in Homo Sacer: l'intégrale 1997-2015 (Paris: Éditions du Seuil, 2016).

${ }^{20}$ See E. Norman Gardiner, Athletics of the Ancient World (Oxford: Clarendon Press, 1955), pp. 19-22. However in so doing Homer, and Nietzsche following him, confuse combatants with mere contestants, competitors, those who struggle within a unity. See Nietzsche, "Homer's Contest," in On the Genealogy of Morality, ed. Keith Ansell-Pearson, trans. Carol Diethe (Cambridge: Cambridge University Press, 2007, 2nd ed.). The Hebrew Bible, by contrast, looks with disfavour upon those who fail to uphold the difference, as when it describes the Philistines as using the term for "to play" or "to make sport" (lesakhek, לשׁשֶ) to refer to a fight to the death. See Judges 16:25-27, which some interpret as portraying Samson as having to fight wild animals for the Philistines' amusement. This is one reason why we might say that, unlike the Homeric poems, the Hebrew Bible is meant to be taken seriously. For others, see Erich Auerbach, Mimesis: The Representation of Reality in Western Literature, trans. Willard R. Trask (Princeton: Princeton University Press, 2003 [1946]), ch. 1.

${ }^{21}$ See, for example, Republic 487B-C.

${ }^{22}$ The Laws of Plato, trans. Thomas L. Pangle (Chicago: University of Chicago Press, 1980), 803C.
} 
Most ancient Greeks surely didn't go this far, however, which is why we may assume that they were aware of how game playing is an activity that must be to some degree circumscribed, forming an "island" of fun amidst the seriousness of the practical. Indeed, there seems to be something virtually primordial about the idea; playgrounds, after all, are almost invariably marked off. ${ }^{23}$

Getting a grasp of precisely how games stand apart from the practical can be tricky, however. While it's true that games are inherently unproductive, property may still change hands between players. So we can expect gamblers, at least, to complain that Johan Huizinga goes too far when he suggests that games can serve no material interest. ${ }^{24}$ Still, to play a game is not per se to create wealth of any kind, because while some people may certainly play for a living, whatever remuneration they receive is best understood as coming from outside of the game. I base this on a fundamental distinction: between the ends that are internal to a game, on the one hand, and those which, being situated in practical life, are external to it, on the other. This accounts for why, even though games are inherently unserious, we can still choose to take them more or less seriously. Think of ice hockey. Those who play it professionally have good reasons to be sober about it, since it serves as a source of both income and recognition. We might say something similar about its fans - at least in a country like Canada, where the game has long claimed a place as an important pastime, such that a great deal of national pride has become wrapped up in it. But while values such as earning a living, gaining recognition, and upholding national pastimes can all be associated with ice hockey, thereby making it serious by connecting it to practical life, they all nevertheless remain external to the game. This is because the only ends one needs to meet to actually play it are those such as scoring goals, making saves, and so on. These, then, are internal, since they can be

\footnotetext{
${ }^{23}$ As the historian Johan Huizinga, in particular, has emphasized: Homo Ludens: A Study of the Play Element in Culture (Boston: Beacon Press, 1950), esp. pp. 4, 8-9; see also Georg Simmel, Fundamental Problems of Society (Individual and Society), in The Sociology of Georg Simmel, ed. and trans. Kurt H. Wolff (Glencoe, IL: The Free Press, 1950), pp. 42-43. Erving Goffman, however, refuses to accept that games stand apart from our practical social encounters, since he believes that both aim for the very same thing, namely "euphoria." See Goffman, "Fun in Games," in Encounters: Two Studies in the Sociology of Interaction (Indianapolis: Bobbs-Merrill, 1961). But this is to ignore Aristotle's warning against confusing happiness, or well-being, with the enjoyment that can come from playing games: Nichomachean Ethics 1176b-1177a.

${ }^{24}$ See Huizinga, Homo Ludens, p. 9. Roger Caillois, in particular, has complained of how Huizinga's definition of games would force us to exclude bets and games of chance: Man, Play, and Games, trans. Meyer Barash (New York: The Free Press of Glencoe, 1961), p. 5.
} 
affirmed for no other reason than that they make playing the game possible. And that is precisely why our attitude towards them can be playful rather than serious. ${ }^{25}$

Kurt Riezler evidently sees what is going on here. As he writes, when it comes to playing (for fun),

we are partly concerned but without linking this partial concern to other parts or to the whole of our concern. It does not count. In severing the link that connects this part with other parts we treat a "partial" concern as if it were no part of anything. Thus the part, not being conceived of as part, is not a part. In the seriousness of ordinary life all partial concern remains partial because it is connected with some of or all our other concerns. The "merely" in our playing seems to point not to a partial concern, but to a distinction in which our concern in playing is separated from our other concerns. ${ }^{26}$

Such playing, in other words, is different from the serious activities of practical life. The latter reflect concerns that are parts of practical life as a whole, whereas to play is to stand, in a sense, apart from that whole. This division is reinforced by the fact that unlike with, say, the need to work, players are supposed to be wholly free to enter the game - to take the leap - or not. Indeed, the freedom of players to choose to play is essential to one sense (the contractualist) of the idea of fair play: if people agree to play a game, then they can be said to have chosen to impose its rules on themselves and so they should respect those rules. ${ }^{27}$ All of which is to say that the more players play not simply because of a "love of the game" ("amateur," it's worth noting, comes from the Latin amare, "to love"), but because they are driven by values external to it, values situated in practical life - indeed the more those values are seen to influence the game in any way - then the

\footnotetext{
${ }^{25}$ My way of distinguishing between internal and external goods thus differs from Alasdair MacIntyre's in his After Virtue: A Study in Moral Theory (Notre Dame, IN: Notre Dame University Press, 2007, 3rd ed.), pp. 187-91. To me, values that are strictly internal to given practices are "aesthetic" because, just like those internal to games, they are independent of the goods of practical life as a whole.

${ }^{26}$ Riezler, "Play and Seriousness," Journal of Philosophy 38, no. 19 (Sept. 1941): 505-17, p. 511.

${ }^{27}$ See Heather Sheridan, "Conceptualising 'Fair Play': A Review of the Literature," European Physical Education Review 9, no. 2 (2003): 163-84, pp. 170-72. The idea of fair play is of relatively recent vintage, it having originated with the crystallisation of certain crude and dangerous sports into ball games with defined rules that took place within the public schools of Victorian Britain. See Charles Tennyson, "They Taught the World to Play," Victorian Studies 2, no. 3 (March 1959): 211-22, p. 212. Of course, this was part of a much deeper and more widespread development. See Charles Taylor's discussion of "the rise of the disciplinary society" in his A Secular Age (Cambridge, MA: Harvard University Press, 2007), ch. 2, parts 2-5.
} 
more people will worry that the spirit of the game has been undermined. And the less fun will it be to play it.

The distinction between games and practical life also depends, I have claimed, upon the degree of formality: the more formal the game, the sharper the distinction. Think of a heterosexual man who is willing to do no more than informally "play around" with a woman. We say that he doesn't have serious intentions towards her since he's excited by "the chase" and hopes only "to score," not to form a genuine relationship. He wants "to attract her without caring to possess her in the stricter sense," as the author of "The Seducer's Diary" puts it. ${ }^{28}$ True, he sees her body as an object which could satisfy his sexual urges, and so he's to this limited extent serious about her, but he nevertheless remains distant from her as a person. Once his desires have been satisfied, he wishes to go no further; she's to have no connection with the rest of his life.

The playing of a formal game (ice hockey, chess, and so on) stands even more starkly apart from the practical and consists of behaviour that can be considered even less serious. Often, this playing is said to take place within a wholly independent order, "a little cosmos of its own." 29 Whereas the practical dimension as a whole is, as pluralists claim, unsystematizable, formal games are governed by what John Searle has called "constitutive rules" and such rules, Searle tells us, "come in systems." ${ }^{30}$ Among other things, this means, as we've noted, that they do not contradict each other; if they did then it would become exceedingly difficult to play the game. Yet there are many systematically unified practices that we do not consider games: think of a recipe for making dinner, or of the procedures that you must follow when applying for a professional post. However, these things are not done to fulfil some strictly internal end - on the contrary, their basic point is the achievement of something (a meal, a job) that is useful to us in our practical lives. And so we take them seriously, since they are directly connected to those lives, serving as extensions of them. Not so the ends that are internal to a game, which is precisely why we can choose to "take a break" and play it.

\footnotetext{
${ }^{28}$ Kierkegaard, "The Seducer's Diary," in Either/Or: Part I, eds. and trans. Howard V. and Edna H. Hong (Princeton: Princeton University Press, 1987 [1843]), p. 307.

${ }^{29}$ Riezler, p. 505.

${ }^{30}$ Searle, Speech Acts: An Essay in the Philosophy of Language (Cambridge: Cambridge University Press, 1969), p. 36 .
} 


\section{II}

Thus, games are independent, to a degree, from practical life, since they (i) embody strictly internal ends, that is, those which are affirmed for nothing other than the sake of the game. Furthermore, (ii) formal games, being governed by systematically unified rules, are ordered, whereas practical life as a whole is not. Not that I mean for these two to serve as a set of necessary and sufficient conditions for some analytic definition of "game." I agree with Wittgenstein that the concept is not definable in this way. ${ }^{31}$ Still, enough has been said about it that we should be ready for the comparison with Rawls' conception of justice.

Taking the conditions in reverse order, we can begin by noting how, in the first footnote to a very early paper, Rawls tells us that he conceives of social practices as systematic: "I use the word 'practice' throughout as a sort of technical term meaning any form of activity specified by a system of rules which defines offices, roles, moves, penalties, defences, and so on, and which gives the activity its structure. As examples one may think of games and rituals, trials and parliaments."32 Rawls even goes on to illustrate his understanding of the nature of social practices by drawing parallels with the behaviour of those who play baseball. ${ }^{33}$ Evidently, he believes such practices are governed by constitutive rules, something he states explicitly in A Theory of Justice when he describes institutions as "a set of constitutive conventions. Just as the rules of games do, they specify certain activities and define certain actions." ${ }^{34}$ Rawls is thus clearly an exponent of what Hubert L. Dreyfus has called "theoretical holism," in which human practices can be captured by a theory, "the systematic interrelation of distinguishable elements," precisely because they reflect unified belief systems. ${ }^{35}$

\footnotetext{
${ }^{31}$ See Wittgenstein, Philosophical Investigations, eds. G.E.M. Anscombe, R. Rhees, and G.H. von Wright, trans. Anscombe (Oxford: Basil Blackwell, 1968, 3rd ed.), § 66, 68-69, 75-76. For an interesting, if failed, attempt at providing an analytic definition, see Bernard Suits, The Grasshopper: Games, Life and Utopia (Peterborough, ON: Broadview Press, 2014, 3rd ed.). On why it fails, see Norman Geras, "Games and Meanings," in Stephen de Wijze, Matthew H. Kramer, and Ian Carter, eds., Hillel Steiner and the Anatomy of Justice: Themes and Challenges (New York: Routledge, 2009).

${ }^{32}$ Rawls, "Two Concepts of Rules," in Collected Papers, ed. Samuel Freeman (Cambridge, MA: Harvard University Press, 1999), p. 20 n. 1.

${ }^{33}$ Ibid., pp. 37-38.

${ }^{34}$ Rawls, A Theory of Justice, p. 303.

${ }^{35}$ Dreyfus, "Holism and Hermeneutics," in Skillful Coping: Essays on the Phenomenology of Everyday Perception and Action, ed. Mark Wrathall (Oxford: Oxford University Press, 2014), p. 129.
} 
Whence Rawls' faith in the project of constructing a theory of justice. Imagine coming upon a group of people in a park who are playing a game you haven't seen before. You ask about its rules, but they say they've never really formulated them. So you offer to do so yourself, and this leads you to propose reforms - reforms which, after having been tested by the players, you then reformulate, moving back and forth between practice and theory in this way until you settle on a complete and systematically unified rulebook. Now this is precisely how political theorists are supposed to carry out the task that Rawls calls "political constructivism": they are to interpret "the great game of politics" in a way that achieves "reflective equilibrium" around a systematically unified set of principles of justice. ${ }^{36}$

Of course, that set must be one to which everyone is willing to conform and which does not unfairly advantage anyone. This is where Rawls" idea of "the original position" comes in. It's the perspective attained by entertaining a hypothetical: imagine you have stepped behind a "veil of ignorance," so to speak, such that you've knowledge of neither your personal comprehensive doctrine, nor your social position, nor your capacities as an individual. What, then, would be the principles that you would choose for politics? To begin, you would surely evaluate their ability to secure "primary goods," those that any rational person needs, regardless of their preferred way of life. ${ }^{37}$ Yet not knowing who, specifically, you are, you wouldn't be able to choose those principles that favoured you in any way. ${ }^{38}$ Notice how these very same standards apply to someone in the original position who has had to choose which game to play. They too must do so on the basis of whether they could realise the things that (almost) anyone would want from a game - including fun, competition, the fair treatment of players, as well as their right to make a variety of plays. So they too must be assured that no one else was able to pick the game best suited to their particular talents.

\footnotetext{
${ }^{36}$ See Rawls, A Theory of Justice, pp. 18-19, 42-45; and Political Liberalism, pp. 89-129. The expression "the great game of politics" is from Rawls, "The Idea of Public Reason Revisited," in The Law of Peoples: with 'The Idea of Public Reason Revisited' (Cambridge, MA: Harvard University Press, 1999), p. 140; and Lectures on the History of Political Philosophy, ed. Samuel Freeman (Cambridge, MA: Harvard University Press, 2007), p. 4. Note that, in the former, it appears in scare quotes and, in the latter, it is accompanied by a footnote indicating that the expression was the name of a column in the Baltimore Sun in the 1920s and '30s.

${ }^{37}$ See Rawls, A Theory of Justice, § 15; "Social Unity and Primary Goods," in Collected Papers; and Political Liberalism, chs. 2 § 5.3, 5 § 3-4.

${ }^{38}$ See Rawls, A Theory of Justice, § 4; and Political Liberalism, pp. 23-24.
} 
Rawls likewise conceives of his principles' ordering as stable in much the same way that the rules of a formal game are stable. When he describes his ideal society as well-ordered, he means three things: that everyone accepts its principles; that its basic structure satisfies these principles; and that people generally comply with them in practice. ${ }^{39}$ All three, of course, also apply to games and their players: there must be a consensus about the rules; the set-up of the game must satisfy those rules; and the players must actually comply with them as they play (i.e. they should be neither cheats nor spoil-sports). Moreover, just as a "publicly recognized conception of justice establishes a shared point of view from which citizens' claims on society can be adjudicated," ${ }^{20}$ so may players appeal to a common rulebook - through the neutral referee applying it - in order to determine how to play. Only when it comes to justice, that referee will tend to be found sitting on the bench of a country's supreme court. ${ }^{41}$

The well-ordered society, moreover, is "a system that is in equilibrium," by which Rawls means that it can be considered stable "whenever departures from it, caused say by external disturbances, call into play forces within the system that tend to bring it back to this equilibrium state." ${ }^{42}$ This, too, is just like a game. One of the reasons Rawls loved baseball so much is that he believed its rules are in total equilibrium:

from the start, the diamond was made just the right size, the pitcher's mound just the right distance from home plate, etc., and this makes possible the marvellous plays, such as the double play. The physical layout of the game is perfectly adjusted to the human skills it is meant to display and to call into graceful exercise. Whereas, basketball, e.g., is constantly (or was then) adjusting its rules to get them in balance. ${ }^{43}$

\footnotetext{
${ }^{39}$ See Rawls, A Theory of Justice, § 69; and Political Liberalism, pp. 35-40.

${ }^{40}$ Rawls, Political Liberalism, p. 35.

${ }^{41}$ See ibid., pp. 231-40. Thus while current U.S. chief justice John Roberts would surely not agree with the substance of Rawls' principles, he would concur with the latter's conception of his role. As Roberts declared during his confirmation hearings, "Judges are like umpires." Quoted in Bruce Weber, "Umpires v. Judges," New York Times, July 12, 2009.

${ }^{42}$ Rawls, A Theory of Justice, p. 400.

${ }^{43}$ Rawls, “The Best of All Games,” Boston Review, 1 March 2008.
} 
So when something happens to upset the balance, there needs to be compensation. Imagine some kids are playing street hockey while wearing in-line skates. It begins to rain, making skating dangerous, so they remove their skates and continue to play while wearing sneakers. In this way, they uphold the basic principles of the game while maintaining its equilibrium.

The well-ordered society is supposed to react to disturbances in the same way. Say there's a terrorist bombing and more attacks are likely. In response, the state increases security while striving to respect civil liberties as much as possible. In this way, the society's stability can be described as relying on its capacity to return to equilibrium. And notice the assumption here: that the challenges to that equilibrium are in no sense considered opportunities for progress, for bringing the society to a new and better state overall by virtue of transformations arising from the disturbances. For there appears to be nothing fundamental to be learned about justice from dealing with them; we are, rather, to be guided by "non-ideal theory," which is itself able to present a "reasonably clear picture of what is just" only because it relies upon the already-developed ideal theory for direction. ${ }^{44}$ Evidently, Rawls' approach reflects that of a "conservative" rather than "dissipative" or genuinely complex system; the latter interacts with the environment around it in a way that may lead it to transform its structures rather than maintaining them and returning to its old equilibrium. ${ }^{45}$ We see the very same process with games. While there are times when players may have to do such things as alter their equipment in order to keep playing, such changes can be considered minimal in that they respect the game's rules, which remain fixed (at least during play).

So just like with a game, fundamental conflict, the kind that could undermine and transform a system's order, is excluded from Rawls' ideal society, his "realistic utopia." "46 But this makes me think of the dystopia in Aldous Huxley's Brave New World, where to live is, as one character describes, "to play the game" - one that, its Controller boasts, constitutes "the stablest equilibrium in history." 47 In fact, much as Huxley's world is said to have a "Centre" that stands apart from the "Savage Reservations" around it, ${ }^{48}$ Rawls' "political" society stands apart from the various

\footnotetext{
${ }^{44}$ Rawls, A Theory of Justice, p. 216.

${ }^{45}$ See Grégoire Nicolis and Ilya Prigogine, Exploring Complexity: An Introduction (New York: W.H. Freeman and Company, 1989), ch. 2, § 1-2.

${ }^{46}$ Rawls, The Law of Peoples, p. 12.

${ }^{47}$ Huxley, Brave New World (London: HarperCollins, 1932), pp. 38, 207.

48 Ibid., p. 78.
} 
cultures of everyday practical life, those which express comprehensive doctrines. True, in $A$ Theory of Justice he says only that the principles governing the former may not be relevant to the latter, since they are concerned with "the basic structure of society,"

the way in which the major social institutions distribute fundamental rights and duties and determine the division of advantages from social cooperation [ . . . meaning that they] may not work for the rules and practices of private associations or for those of less comprehensive social groups. They may be irrelevant for the various informal conventions and customs of everyday life; they may not elucidate the justice, or perhaps better, the fairness of voluntary cooperative arrangements or procedures for making contractual agreements. ${ }^{49}$

By the time of Political Liberalism, however, Rawls is clear that his principles are strictly "political," and so are distinct from those of comprehensive doctrines. For they are

expressed in terms of certain fundamental ideas seen as implicit in the public political culture of a democratic society. This public culture comprises the political institutions of a constitutional regime and the public traditions of their interpretation (including those of the judiciary), as well as historic texts and documents that are common knowledge. Comprehensive doctrines of all kinds - religious, philosophical, and moral - belong to what we may call the "background culture" of civil society. This is the culture of the social, not of the political. It is the culture of daily life, of its many associations: churches and universities, learned and scientific societies, and clubs and teams, to mention a few. ${ }^{50}$

One might object that this says only that the principles of justice are conceptually distinct from those of everyday practical life. To be independent in the way that the rules of a game are, these principles must uphold ends which, to recall our first condition, are strictly internal: one must be

\footnotetext{
${ }^{49}$ Rawls, A Theory of Justice, pp. 6, 7.

${ }^{50}$ Rawls, Political Liberalism, pp. 13-14.
} 
able to endorse them for no other reason than what we might describe as a "love of justice." Yet Rawls himself tells us that the hazards arising from "our sentiment of justice" are "on a par with the hazards of love," 51 a claim which, following his "political not metaphysical" turn, we should interpret as invoking none other than the amateur player's love of the game.

So justice, as Rawls came to conceive of it, is capable of standing alone, hence of being neither intrinsically nor instrumentally linked to practical life. He makes clear that there's no intrinsic link when he specifies that a political conception is a "freestanding view" independent of practical life's comprehensive doctrines, and so something that can be "expounded apart from, or without reference to, any such wider background." 52 It works "entirely within [its] domain and does not rely on anything outside it." ${ }^{53}$ As for an instrumental link, Rawls rules this out when he asserts that a political conception is more than a mere modus vivendi, more than some "social consensus founded on self- or group interests, or on the outcome of political bargaining." ${ }^{54}$ Because justice must be affirmed "for its own sake" 55 and, for this reason, it's just like the internal ends of a game.

As for involvement by citizens in the politics that respects justice as so conceived, Rawls distinguishes between how they may come to do so, which he says must be entirely voluntary, and how they and all other citizens enter and leave society as a whole, which for theoretical purposes he limits to the wholly non-voluntary paths of birth and death. ${ }^{56}$ Because to Rawls, "there is no political obligation, strictly speaking, for citizens generally." ${ }^{\prime 57}$ Or as we might wish to put it here: they don't have to play if they don't want to.

So it should come as no surprise that Rawls appeals to the principles of fair play to explain why those participating in politics must respect his conception of justice as well as comply with the other requirements of any special role they play in the polity. Once, he went much further, invoking fair play as the reason why everyone should obey the law, but he ultimately came to

${ }^{51}$ Rawls, A Theory of Justice, p. 502; see also Susan Mendus, “The Importance of Love in Rawls's Theory of Justice," British Journal of Political Science 29, no. 1 (Jan. 1999): 57-75.

52 Rawls, Political Liberalism, p. 12.

53 Ibid., p. 374.

${ }^{54}$ Ibid., p. 147; see also A Theory of Justice, p. 416.

${ }^{55}$ Rawls, A Theory of Justice, p. 8; Political Liberalism, pp. 50, 54, 92, 148-49.

${ }^{56}$ See Rawls, A Theory of Justice, p. 302; and Political Liberalism, p. 12.

${ }^{57}$ Rawls, A Theory of Justice, p. 98. 
anchor this obligation in the "natural duty of justice" instead ${ }^{58}$ For he concluded that our political duties must be limited to cases of wholly voluntary consent, noting that "we acquire obligations by promising and by tacit understandings, and even when we join a game, namely, the obligations to play by the rules and to be a good sport." ${ }^{, 59}$ This is why he asserts that, when it comes to respecting justice as fairness, as long as the institutions are just and practitioners have voluntarily chosen to participate in them, then they should do their fair share as defined by the conception of justice. ${ }^{60}$ True, he does say that a legal system based upon the conception will be distinct from other associations such as games because of "its comprehensive scope and its regulative powers."61 But this difference remains one of degree rather than kind. Think of it this way: even if we vastly increased the number and types of possible penalties in ice hockey, as well as replaced the penalty box with jail, that would certainly raise the stakes but, at the end of the day, it would remain a game.

Perhaps, then, Rawls and his followers will concede that his well-ordered "political" society is a kind of game. They may think they're taking it seriously, of course, but then that's because they aren't playing; rather, they're formulating or defending its rules. They are the game designers. This, incidentally, is why they may consider its impact upon the world outside of it. As Rawls writes:

We cannot, in general, assess a conception of justice by its distributive role alone, however useful this role may be in identifying the concept of justice. We must take into account its wider connections; for even though justice has a certain priority, being the most important virtue of institutions, it is still true that, other things being equal, one conception of justice is preferable to another when its broader consequences are more desirable. ${ }^{62}$

\footnotetext{
${ }^{58}$ See Rawls, "Legal Obligation and the Duty of Fair Play," in Collected Papers; and A Theory of Justice, p. 302.

${ }^{59}$ Rawls, A Theory of Justice, p. 97.

${ }^{60}$ See Rawls, A Theory of Justice, pp. 96-97. Ronald Dworkin has also called for governments to operate on the basis of principles of fair play. See his "Principle, Policy, Procedure," in A Matter of Principle (Cambridge, MA: Harvard University Press, 1985), pp. 84-85.

${ }^{61}$ Rawls, A Theory of Justice, p. 207.

${ }^{62}$ Ibid., p. 6.
} 
This is how Rawlsians reckon with the consequences of their game of justice for ends that are external to it. Yet it cannot even be considered on par with what are sometimes called "serious games" - those war games, video games, and simulations that are played primarily for purposes, not least educational, that lie outside them. ${ }^{63}$ Since the ends of Rawlsian justice are internal, ordinary citizens - that is, its players - are supposed to affirm them for their own sakes.

Indeed, they are supposed to do so even when play has had to stop because an issue has arisen over the application of the rules. At such times, Rawls would have citizens engage in "public reason," a form of deliberating said to be exemplified by none other than the supreme court justice. ${ }^{64}$ This is why, while citizens are allowed to invoke their comprehensive doctrines when it comes to ordinary politics, they must ignore them when faced with issues that touch on the basic structure. Because at such times, they effectively become their own referees; any arguments they advance must thus be articulated in ways that all of their fellow citizens could reasonably accept, something that would be impossible should they refer to material from outside of the shared theory of justice. ${ }^{65}$ After all, while players can be expected to play in ways that uphold their team's unique style, such things must be set aside whenever the game has to be suspended so there can be deliberations over the application of the rules, since to appeal to some authority or even way of thinking outside of the rulebook couldn't possibly be fair. Those who engage in public reason must therefore avoid nonpublic considerations. And if they ask why, Rawls would surely respond with "For the sake of justice." And if we followed this with "Why justice?" then the answer would surely be "For its own sake."

${ }^{63}$ See Clark C. Abt, Serious Games (New York: Viking Press, 1970). Rawls is well aware of the educational advantages of serious games. During a course lecture about the "reasoning game" (which is how he used to refer to the original position) he admits that some will object that this is "a kind of frivolous way to think about it: it's a game yet this is supposed to be a very important subject of political philosophy, one where we're determining how society is to be run. Now certainly that's important - people fight about it all the time and even kill each other on occasion so why talk about it as a game? Only so you won't get intellectually confused and start asking questions that are really irrelevant as it will turn out. It helps to think of very important vital things in terms that reduce the emotional involvement." From "Modern Political Philosophy - Lecture 2," starting at 28:36. I imagine Rawls changed the name to the original position because he was unaware of the existence of cooperative, as distinct from competitive, games: "The idea of a game does not really apply, since the parties are not concerned to win but to get as many points as possible judged by their own system of ends." A Theory of Justice, p. 125.

${ }^{64}$ See Rawls, Political Liberalism, ch. 7; and "The Idea of Public Reason Revisited."

${ }^{65}$ See Micah Schwartzman, "The Completeness of Public Reason,” Politics, Philosophy \& Economics 3 , no. 2 (2004): 191-220. 
All of which leads me to conclude that Rawlsian justice is a form of what Susan Sontag has called pure or naïve camp, since it simply does not know itself to be unserious. ${ }^{66}$ It doesn't recognize how, whereas a game is a game, politics is a fundamentally serious - because practical - activity, one that cannot be well-ordered because it takes place within the inherently disunified world of human affairs, a world from which the threat of tragic ethical loss cannot be eliminated.

But so what? How would adopting Rawls' theory, or one like it, be harmful to political practice? Surely this is the important question. My answer is that it can be said to have this effect in two ways: one with respect to those who participate directly in politics, and the other as it relates to those who do no more than follow it.

Regarding the practitioners, treating politics as if it were a game encourages them to engage in competitive, hence adversarial, behaviour. True, not all games are competitive, but most are, competition being virtually their raison d'être, not to mention a large source of the fun. And if those involved in politics are faced with a conflict and they see themselves as players in a game, then they certainly will compete. This means they will view each other as not merely "opponents" but also "adversaries": because when the basic objective is to defeat a competitor, then one can only win if the other loses. The main problem here, as I see it, is that this makes it virtually impossible for those involved to respond to their conflict by engaging in conversation, which is an extremely fragile mode of dialogue that aims to realize and develop the common good. Those who would converse over conflicting values do so because they hope to transform them in a reconciliatory way, to devise a solution to the conflict that genuinely benefits all parties. If there's the slightest rigidity in thought, however - if we take the "hard line" because we're defensive, and we're defensive because we sense that we are facing an adversary - then it becomes exceedingly difficult to undergo the sometimes radical changes that make reconciliation possible. ${ }^{67}$

Rigidity also derives from a commitment to a previously formulated system of rules, since this significantly limits what may be transformed. That is another reason why the citizens who would respect Rawls' theory are almost certain to become adversaries when they conflict. Hence the irony in how Ronald Dworkin, another systematic theorist, chose to begin one of his books: he

\footnotetext{
${ }^{66}$ See Sontag, "Notes on 'Camp'," in Against Interpretation and Other Essays (New York: Farrar, Straus \& Giroux, 1966), nos. 18-19, 22-23.

${ }^{67}$ For more on the distinction between opponents and adversaries, and on its relevance to dialogue, see my "Opponents vs. Adversaries in Plato's Phaedo," in Patriotic Elaborations: Essays in Practical Philosophy (Montreal and Kingston: McGill-Queen's University Press, 2009).
} 
calls for shared common ground in a set of political principles that will counter what he, along with many others, has come to see as the alarmingly belligerent nature of contemporary U.S. politics. To Dworkin, Americans are "no longer partners in self-government; our politics are rather a form of war." 68

Dworkin is not, like Rawls, a monist only with regards to politics. While he agrees that "political values are finally unitary, not plural," his monism also encompasses morality, indeed all of the practical. ${ }^{69}$ Nevertheless he, too, advocates a political vision that's based on two systematically interlocked principles. And just as with Rawls' public reason, Dworkin shares in the belief that we require a framework of principles for real argument to be possible. But notice what's meant by this: "I mean 'argument'," Dworkin writes, "in the old-fashioned sense in which people who share some common ground in very basic political principles debate about which concrete politics better reflect these shared principles." 70 Now while this certainly is one of the old-fashioned senses of the term (parties advance their reasons, "score points" on each other, and hope to win the debate), there's also another sense: argument as what is exchanged between the interlocutors of a conversation. It also requires that there be things held in common; but they are best understood as transformable, value-expressing practices rather than as grounding principles. ${ }^{71}$ And surely it's more of this kind of argument that we need if we're concerned about an overly adversarial politics. Dworkin, however, seems to have room only for competitive debate, which is why, when faced with a combative citizenry, he can do no more than insist that "we need to find ways not merely to struggle against one another about these issues, as if politics were contact sports."72 As if politics as non-contact sports were acceptable.

\footnotetext{
${ }^{68}$ Dworkin, Is Democracy Possible Here? Principles for a New Political Debate (Princeton: Princeton University Press, 2006), p. 1. Or as Rawls laments, "much political debate betrays the marks of warfare." Justice as Fairness: A Restatement, ed. Erin Kelly (Cambridge, MA: Harvard University Press, 2001), p. 118. See also James Davison Hunter, Culture Wars: The Struggle to Define America (New York: Basic Books, 1991); Hunter, Before the Shooting Begins: Searching for Democracy in America's Culture War (New York: Macmillan, 1994); and Keven Vallier, Must Politics Be War? Restoring Our Trust in the Open Society (Oxford: Oxford University Press, 2019).

${ }^{69}$ Dworkin, Is Democracy Possible Here?, p. 155; and see Dworkin, Justice for Hedgehogs.

${ }^{70}$ Dworkin, Is Democracy Possible Here?, p. 5.

${ }^{71}$ See my From Pluralist to Patriotic Politics: Putting Practice First (Oxford: Oxford University Press, 2000), esp. ch. 3; and my "Patriotic, Not Deliberative, Democracy" and "From Moderate to Extreme Holism," both in Patriotic Elaborations.

${ }^{72}$ Dworkin, Is Democracy Possible Here?, p. xi.
} 
So we may assume that, just as with Rawls' justice as fairness, Dworkin's “partnership democracy" is going to be a highly adversarial affair. ${ }^{73}$ Both theorists' ideal citizens are indeed partners, but only in the sense of those who compete within the same game.

Their competition, moreover, takes two main forms. The first is associated with those who practice politics as members of competing parties or interest groups. And the second arises when such competitions have broken down and there are disagreements over what Rawls calls the basic structure of society. However, it seems to me that, at such times, Dworkin has the more realistic sense of what may take place. Because just as when a game must be suspended since questions have arisen over the application of its rules, Dworkin would have the more articulate citizens take on a role comparable to that of a team captain and plead their case before the justices of the supreme court, the referees. One thinks of Dworkin's many interventions in the New York Review of Books as an example. Rawls, by contrast, would have citizens somehow switch altogether from competition to cooperation and engage in public reason, becoming, as we've noted, their own referees. ${ }^{74}$ That there's something schizophrenic about this "dualism" ${ }^{75}$ should be obvious. What is less clear is why Rawls considers it plausible. But if we follow Dworkin there are at least two reasons why we should expect that the pleading he recommends will go on in the adversarial spirit of before. First, the tendency of lawyers to advocate positions in the language of rights encourages their conflict to be viewed as a "clash of rights" and this is simply too abstract and adversarial to allow for real conversation. ${ }^{76}$ And second, because that is simply how it is done: no self-respecting lawyer today ever knowingly pleads in a way that might serve the interests of the opposing side. ${ }^{77}$

\footnotetext{
${ }^{73}$ See ibid., pp. 143-47.

${ }^{74}$ To Dworkin, when it comes to deciding hard cases judges must ask about legislative purposes and underlying legal principles, just as referees must ask about the point and character of the game that players have consented to play. Notice how those who apply and those who dispute the application of the rules remain separate, in contrast to Rawls' vision. See Dworkin, "Hard Cases," in Taking Rights Seriously (Cambridge, MA: Harvard University Press, 1978), pp. 101-10; and Rawls, Political Liberalism, ch. 6.

${ }^{75}$ Rawls, Political Liberalism, p. xxi.

${ }^{76}$ As I argue in From Pluralist to Patriotic Politics, ch. 7. On why rights talk of the kind favoured by neutralist liberals is inappropriate even for negotiation, see Mary Ann Glendon, Rights Talk: The Impoverishment of Political Discourse (New York: Macmillan, 1991).

77 On the overly adversarial nature of the criminal law, see my "The Scales of Injustice," Windsor Yearbook of Access to Justice 26, no. 1 (2008): 1-24. See also the example offered by Carol Gilligan in her In a Different Voice: Psychological Theory and Women's Development (Cambridge, MA: Harvard University Press, 1993, 2nd ed.), p. 135.
} 
Furthermore, we can also assume that, at least on occasion, what is done will be - and I say this without exaggeration - immoral. For there is something about systematically rule-based contexts that encourages those within them to act in morally questionable ways - as long, that is, as they comply with the rules. Arthur Isak Applbaum has put the point as follows:

Deception and violence are presumptive moral wrongs, but the rules of the game of poker permit deception, and the rules of boxing, football, and hockey permit violence. It is widely believed that lying in poker and tackling in football are morally permissible, and this is so because the rules of the games of poker and football permit such actions. Similarly, it is widely believed that the permissive rules of professional games such as lawyering, business management, and elective politics generate moral permissions to engage in deceptive and coercive tactics that, if not for their game permissibility, would be morally wrong. ${ }^{78}$

Applbaum, however, fails to see that this points to a problem with the very idea of conceiving of these professions as games; indeed, he even goes on to construct an (albeit highly restrictive) argument based on fair play so he can justify certain immoral but rule-respecting behaviours in public and professional life. ${ }^{79}$

I want to turn now to how treating politics as a game can have a detrimental effect on those who follow it. To begin, we need to distinguish between spectators, on the one hand, and the members of an audience, on the other. Spectators are individuals who are independent of, fundamentally untouched by, whatever they're watching, since they treat it as no more than a source of entertainment, as a spectacle. An audience, by contrast, is a communal entity, since its members are concerned with how what's transpiring may affect their common good. Instead of allowing themselves to get "carried away" and appreciate events purely aesthetically, then,

\footnotetext{
${ }^{78}$ Applbaum, Ethics for Adversaries: The Morality of Roles in Public and Professional Life (Princeton: Princeton University Press, 1999), p. 114. See also David Light Shields and Brenda Light Bredemeier, "Moral Development and Behavior in Sport," in Robert N. Singer, Heather A. Hausenblas, and Christopher M. Janelle, eds., Handbook of Sport Psychology (New York: John Wiley \& Sons, 2001, 2nd ed.), esp. pp. 592-93.

${ }^{79}$ See Applbaum, pp. 121-35.
} 
audience members engage critically, practically, as listening interpreters. And this means that, just as with the interlocutors in a conversation, they may have an edifying, transforming experience. ${ }^{80}$ Justice as fairness, however, would make a spectacle of politics. For one thing, just as modern sports spectators are separate from the players they watch, ${ }^{81}$ in Rawls' conception ordinary citizens stand apart from those who participate in politics. For another, as with all contests, the competitiveness of justice as fairness lends it great entertainment value. Because it's surely not just the "members of an orchestra, or players on a team, or even both teams in a game, [who] should take pleasure ... in a good performance, or in a good play of the game, one that they will want to remember." 82 The joys of spectatorship are also encouraged by the "distance" of citizens from the political arena, since it allows them to keep from feeling affected in a deep way. To be so affected they would have to engage as audience members instead, and for this it's necessary to emphasize how, while not directly involved, they are nevertheless still so indirectly. For example, we might point to the ways in which their conversations about politics deep within civil society can influence the state's agenda. ${ }^{83}$ Rawls, however, would have citizens keep their "personal deliberations and reflections about political questions" ensconced within associations, such as churches and universities, that are to make no contribution whatsoever to public discourse about

80 "The primacy of hearing," Hans-Georg Gadamer has written, "is the basis of the hermeneutical phenomenon." Truth and Method, trans. Joel Weinsheimer and Donald G. Marshall (New York: Crossroad, 1989, 2 nd ed.), p. 462. Readers may have noticed the affinities between those I am calling "spectators" and "audience members" and those who attend what Bertolt Brecht has called "dramatic" and "epic" theatre, respectively. See Brecht on Theatre: The Development of an Aesthetic, ed. and trans. John Willett (New York: Hill and Wang, 1992), chs. 8, 13, 18, 20, 53-54; and "Theatre for Learning," trans. Edith Anderson, in Carol Martin and Henry Bial, eds., Brecht Sourcebook (New York: Routledge, 2000). Gadamer, however, fails to distinguish enough between spectators and audience members because he blurs aesthetic and practical, fun and serious forms of play: see Truth and Method, part I, section II.1(A), esp. p. 109. Charles Taylor does the same when he writes about how someone experiencing his first live symphony concert can be "enraptured not only by the quality of the sound [something aesthetic], which was as he had expected quite different from what you get on records, but also by the dialogue between orchestra and audience [something practical]." Taylor, "Cross-Purposes: The Liberal-Communitarian Debate," in Philosophical Arguments (Cambridge, MA: Harvard University Press, 1995), p. 191. Finally, Jeffrey Edward Green overlooks the distinction altogether given his focus on political engagement with one's "eyes" in contrast to one's "voice": The Eyes of the People: Democracy in an Age of Spectatorship (Oxford: Oxford University Press, 2010).

81 "One facet of [modern] specialization was the separation of roles that put increasingly skilful players on the field and increasingly unpracticed spectators on the sidelines." Allen Guttmann, Sports Spectators (New York: Columbia University Press, 1986), p. 83.

${ }^{82}$ Rawls, Political Liberalism, p. 204.

${ }^{83}$ As I do when I argue that we should never draw a solid line between the citizens in civil society and state agents: see From Pluralist to Patriotic Politics, ch. 5; and "Patriotic, Not Deliberative, Democracy," p. 39. 
"constitutional essentials and matters of basic justice." 84 (Unless, presumably, one happens to be a professor publishing in defence of political liberalism.)

It's worth mentioning that citizens as audience members may still find aspects of politics entertaining, not least because attempts at political conversation, whether theirs or politicians', will often break down and so will have to make way for negotiation, which is adversarial and not merely oppositional. Nor should we overlook the necessarily competitive nature of elections. That said, these citizens' critical attitudes should still keep them from getting carried away into "the aesthetic." It will do so, however, only if they manage to avoid the "horse race coverage" of so much contemporary political journalism, whose unrelenting focus on strategy, polls, scandals, and other forms of infotainment has ensured that politics as spectacle virtually rules the day. ${ }^{85}$ Regardless, the point I wish to make here is simply that adopting justice as fairness, or any other such theory, will serve only to further entrench that rule.

Treating politics as a game can also affect citizens by sapping what Rawls would call the "strength" 86 of their sense of justice, thereby undermining a major source of his regime's stability. Justice as fairness, in other words, subverts itself. Riezler's statement above about how play stands apart from our ordinary practical concerns suggests why: when objects are disconnected from practical life then we may still care for them, of course, but no more so than we care for mere games. Sometimes, it goes without saying, game-playing can elicit real passion, but this will always be qualitatively different from the truly deep-seated sense of commitment that we feel towards whatever is important to us in our practical lives. This makes sense since, as Dreyfus has pointed out, "in so far as games work by temporarily capturing our imaginations in limited domains, they cannot simulate serious commitments in the real world." 87 One reason for this inability is that, as we've seen, when values are contained within a unity such as a systematic set of rules, they will at least appear to be sheltered from risk, given that there can be no fundamental conflict between them. And just as overprotective parenting undermines the child, when there's

\footnotetext{
${ }^{84}$ Rawls, Political Liberalism, p. 215.

${ }^{85}$ See Murray Edelman, Constructing the Political Spectacle (Chicago: University of Chicago Press, 1988), ch. 5; James R. Compton, The Integrated News Spectacle: A Political Economy of Cultural Performance (New York: Peter Lang, 2004); and Frank Brettschneider, "Horse Race Coverage," in Wolfgang Donsbach, ed., The International Encyclopedia of Communication, vol. 5 (Malden, MA: Blackwell Publishing, 2008).

${ }^{86}$ See Rawls, Political Liberalism, p. 142; and A Theory of Justice, pp. 436-38.

${ }^{87}$ Dreyfus, On the Internet (New York: Routledge, 2009, 2nd ed.), p. 87.
} 
no danger that we might have to get our hands dirty by compromising our values, then our commitment to them gets weakened. In fact, as Kierkegaard long ago suggested, a loss of commitment is the fate of all spectators, all those whom he identified as members of "the public":

that abstract aggregate ridiculously formed by the participant's becoming a third party. That sluggish crowd which understands nothing itself and is unwilling to do anything, that gallery-public [which] now seeks to be entertained and indulges in the notion that everything anyone does is done so that it may have something to gossip about. $^{88}$

Rawls should expect nothing less from the citizens who follow his "political" politics as if they were watching a game.

\section{III}

One reason why pluralists, or at least the value pluralists that interest me here, cannot be accused of treating politics as a game is that they never see it as standing apart from practical life. In pluralism, politics cannot, without distortion, be made subject to a unified system of rules; nor can it be independent, since the negotiations that pluralists recommend are at least partly instrumental to the values being defended, and these values are fundamentally practical.

The negotiations are only partly instrumental because they are also premised on the virtue of toleration, so those involved are expected to make concessions, and not simply because they have been unable to find a way to eliminate their adversaries. As I interpret pluralists, they endorse toleration because they recognize that, since people are often brought up to affirm different values, it's not their "fault" if their values conflict with yours; they are no less moral agents than you are. In consequence, you should view their positions as morally legitimate and so worthy of a certain minimum of respect. ${ }^{89}$ At the same time, toleration remains just one value among many, so you

\footnotetext{
${ }^{88}$ Kierkegaard, “The Present Age (1846)," in Two Ages: The Age of Revolution and the Present Age, A Literary Review, eds. and trans. Howard V. and Edna H. Hong (Princeton: Princeton University Press, 1978), p. 94; earlier, on p. 91, Kierkegaard implies that the public is unreal because it forms no more than a collection, whereas the ancient citizenry is real because it constitutes a unified, organic whole.

${ }^{89}$ This contrasts with Dworkin. Regarding specifically international politics, he admits that "we must take pluralism into account in deciding what account of human rights could possibly be agreed upon in treaties and enforced in practice" and so he seems to accept that those treaties will have to be "negotiated." Justice for Hedgehogs, p. 339 . But
} 
should not affirm it uncompromisingly. Thus, despite referring to "fairness" in his argument for why conflict resolution should consist in negotiation, Stuart Hampshire means something very different by the term than does Rawls. Instead of the fairness of the neutral referee applying systematically unified rules or principles, Hampshire wants to invoke something disunified, "the kind of imperfect fairness that may emerge from procedures which are themselves compromises, from the relics of history." 90

Yet by giving primacy to negotiation, pluralists can be accused of taking politics too seriously. As we've seen, a politics based strictly on negotiation and compromise is going to be a dirty, and often tragic, affair. As Edward Hall remarks of Berlin, Hampshire, and Williams, none was "into salvation." ${ }^{91}$ I think they go too far, however, since room ought to be made for not only the accommodations of negotiation but also the reconciliations that conversation occasionally makes possible. Because only then can we speak of a politics that is not only tragic but also comic, since reconciliation is the central goal of comedy; as the literary theorist Northrop Frye once put it, "the theme of the comic is the integration of society." 92 Of course, social integration is a serious, practical business, but as everyone knows comedy goes hand in hand with humour. So we can expect a politics that is comic to have at least some playful elements sprinkled upon its surface. Such a politics, in other words, can be serious without also being solemn.

Integration, we should note, requires that there already be some integration to begin with. This means that citizens and their representatives must see themselves as sharing a common good (even if they happen to disagree about its meaning). Only as members of a political community, as friends of a civic sort, can they stand to each other as opponents who are not also adversaries and so have a conversation about what their common good requires. Pluralism, however, ultimately has room for no more than a fragmented, because plural, society, for a multiplicity of partial groupings that

it's evident that we are not to carry out these negotiations in what the value pluralist would consider to be good faith. Because rather than being driven by toleration, we are to view the positions of those we are negotiating with as illegitimate given that they conflict with the abstract political rights which, Dworkin believes, derive from universal principles of dignity. See ibid., pp. 330, 335.

${ }^{90}$ Hampshire, Justice Is Conflict (Princeton: Princeton University Press, 2000), p. 40.

${ }^{91}$ Hall, Value, Conflict, and Order: Berlin, Hampshire, Williams, and the Realist Revival in Political Theory (Chicago: University of Chicago Press, 2020), p. 167.

92 Frye, "Historical Criticism: Theory of Modes," in Anatomy of Criticism: Four Essays (Princeton: Princeton University Press, 1957), p. 43. For more on the comic in politics, see my From Pluralist to Patriotic Politics, ch. 4. 
"clash" when their interests conflict. ${ }^{93}$ This explains the pluralist assumption that conflict is necessarily adversarial - that people can, at best, respond by putting pressure on each other as part of a struggle to reach a balanced accommodation. Conversation is ruled out not only because there's nothing in common to talk about, but also because it's hard to feel secure enough to listen with an open mind when you are being confronted with a demand, with the threat that you will have to give up something important.

The irony here is that pluralists, by encouraging us to take politics too seriously, would bring many of the same problems that come from treating it as a game. For one thing, the absence of conversation means there will be little to learn. More, perhaps, than might come from playing at politics, since negotiation at least requires us to clarify how we should rank and weight our values against our adversary's demands. As negotiators we might also discover the tactics that will produce the concessions we desire. But all this is far from the sometimes profound learning that can come from engaging in genuine conversation, which is about developing a sense of the deeper meanings that our values can have for us. That sense is a prerequisite for transforming those values and reconciling the conflict; we need to learn about their proper place in the whole, in the common good that we share with our fellow citizens.

This we do from within a context of genuine diversity. Diversity, however, is to a significant degree absent from the fragmented world of pluralism. Here's why. Diversity is distinct from mere plurality, understood as the multiplicity of absolutely different things that, having no relation to things outside of themselves, are different only in terms of themselves. It was Hegel who argued that if something "is not itself but its other" then it must be "different from difference [and so a form of] identity." 94 Purely different things, in other words, are ultimately uniform. Not that all pluralists conceive of difference in this way; for some, to say that values are often "incommensurable" with each other is still to accept that they are rationally comparable, despite the inability to capture them within a unified theory. ${ }^{95}$ According to Berlin and Williams, for

93 To Williams, for example, this is what's entailed by accepting a "realistic view of communities," according to which no community could ever serve as "a satisfactorily functioning whole." Williams, "Pluralism, Community and Left Wittgensteinianism," in In the Beginning Was the Deed: Realism and Moralism in Political Argument, ed. Geoffrey Hawthorn (Princeton: Princeton University Press, 2005), p. 37.

${ }^{94}$ The Science of Logic, trans. George di Giovanni (Cambridge: Cambridge University Press, 2010 ), 11.266 (vol. 1, bk. 2, § 1, ch. 2, B, “1. Absolute Difference,” p. 417).

95 Only "agonistic" value pluralists, those who subscribe to a metaethical decisionism, can be said to assume that "incommensurable" means rationally incomparable. See, for example, Max Weber, "Politics as A Vocation," esp. pp. 121-28, and "Science as A Vocation," pp. 147-49, both in From Max Weber: Essays in Sociology, eds. and trans. 
example, when there is a conflict between values it is clearly wrong to hold that "reason has nothing to say (i.e. there is nothing reasonable to be said) about which should prevail over the other." ${ }^{96}$ This can only be so because they assume the values can be compared against a shared background, "the general pattern of life in which we believe." ${ }^{97}$ Nevertheless, given that there's always more than one "we" when it comes to conflict, Berlin and Williams must allow that some values may share little to nothing with others and so come close to being absolutely different. So even their pluralism limits diversity, which brings us back to the idea that there will be little point in listening to the people we're conflicting with, since we can expect them to try and extract concessions but not to learn through shared understandings.

Another problem with pluralism is that its politics can easily become unsustainable, since the appeal to tolerance may simply not be robust enough to maintain good-faith negotiations. When negotiators are faced with a plurality of values they will almost inevitably get the sense that others are justifying their positions by selectively choosing from whichever values happen to be most beneficial to them in a given context - cherry-picking their morality, essentially. This feeling can only breed cynicism and undermine good faith. And when pluralist politics gives way to Realpolitik, then parties will negotiate not because they willingly tolerate each other but because they're too weak to do otherwise. The only way to avoid this and so sustain a culture of good faith, then, is to arrive at the negotiations from failed conversations over the common good. After all, there's a world of difference between negotiating with a (civic) friend, on the one hand, and with a "natural enemy," "98 on the other.

Another reason why pluralist politics is unsustainable is that it saps our commitment to our values. Pluralists are well aware of one form this takes, since they themselves recommend it. I'm thinking of their repeated calls for balance and moderation, which are only to be expected since the willingness to compromise is essential to successful negotiation. But they completely miss the other form, which is due to a feature of their philosophy of language. To pluralists, values lay

H.H. Gerth and C. Wright Mills (New York: Oxford University Press, 1946); and John Gray, Isaiah Berlin: An Interpretation of His Thought (Princeton: Princeton University Press, 2013, 2nd ed.), esp. pp. 1, 44, 46-54, 71, though see p. 155. 307.

${ }^{96}$ Berlin and Williams, "Pluralism and Liberalism: A Reply," Political Studies 41, no. 2 (June 1994): 306-309, p.

${ }^{97}$ Berlin, "Introduction," in Liberty, p. 47.

${ }^{98}$ Hampshire, Innocence and Experience, p. 74. 
claim to two dimensions of meaning: one is contextual, in which values are present in conflicting situations with other values; another is abstract, in which a value's core is said to exist as isolated and (often) universal. ${ }^{99}$ Pluralists sometimes see it as part of their job to supply definitions of these cores, since they assume that the resulting clarity will help us with the practical reasoning required for negotiating value conflicts as they arise. Berlin, for example, writes of the need "to isolate the pure ore of egalitarianism proper," or to prevent whatever "monstrous impersonation" or "sleight of hand" is facilitated by the "confusion" or "confounding" of liberty with other values. ${ }^{100}$ Yet perhaps the most purely abstract articulations of values are, he suggests, provided by the leaders of oppressed groups, those whose "noble eloquence" is especially evident when

for a brief instant their utterance has a universal quality ... The formal possession of power is unfavourable to that truly disinterested eloquence - disinterested partly at least because fulfilment is remote, because principles shine forth most clearly in the darkness and void, because the inner vision is still free from the confusions and obscurities, the compromises and blurred outlines of the external world inevitably forced upon it by the beginnings of practical action. ${ }^{101}$

Presumably, this is when values are at their most powerful, and so most able to motivate us to uphold them, because they've yet to undergo the compromises forced upon them by conflicts with other values in practical contexts. So it is when they are in this abstract state that we might expect their supporters to be the most committed to them.

The reality is quite the opposite, however. When it comes to abstractions, our commitments tend to be fickle at best, volatile at worst. Berlin's intellectual hero, Alexander Herzen, was well aware of the latter, which accounts for Berlin's description of him as having a deep distrust of

${ }^{99}$ See, for example, Berlin, "An Introduction to Philosophy," in Bryan Magee, ed. and interviewer, Men of Ideas (London: BBC, 1979), p. 33; and Williams, "Saint-Just's Illusion," in Making Sense of Humanity: And Other Philosophical Papers 1982-1993 (Cambridge: Cambridge University Press, 1995), p. 137.

100 Berlin "Equality," in Concepts and Categories: Philosophical Essays, ed. Henry Hardy (Princeton: Princeton University Press, 2013, 2nd. ed.), p. 134; "Two Concepts of Liberty," pp. 180-81, 200-201, 204. Other texts where pluralists offer definitions of isolated values include Hampshire, Freedom of the Individual (London: Chatto \& Windus, 1975, 2nd ed.); and Williams, "From Freedom to Liberty: The Construction of a Political Value" and "The Idea of Equality," both in In the Beginning Was the Deed.

${ }^{101}$ Berlin, "Political Ideas in the Twentieth Century," p. 64. 
the great, official historical goals - progress, liberty, equality, national unity, historic rights, human solidarity - principles and slogans in the name of which men had been, and doubtless would soon again be, violated and slaughtered, and their forms of life condemned and destroyed .... Herzen saw danger in the great magnificent abstractions the mere sound of which precipitated men into violent and meaningless slaughter - new idols, it seemed to him, on whose altars human blood was to be shed tomorrow as irrationally and uselessly as the blood of the victims of yesterday or the day before, sacrificed in honour of older divinities - Church or monarchy or the feudal order or the sacred customs of the tribe, that were now discredited as obstacles to the progress of mankind. [Thus did Herzen exhibit] scepticism about the meaning and value of abstract ideals as such, in contrast with the concrete, short-term, immediate goals of identifiable living individuals. ${ }^{102}$

Berlin evidently does not follow Herzen all the way here, as we can see from his analytic work of mining the "pure ore" of moral concepts. Nevertheless, both can be said to miss how, over the long term, the abstract articulation of values is a form of aestheticization; by converting the values into simulacra, it serves only to undermine them. To repeat the Kierkegaardian point: deep commitment is ultimately a matter of presence in practical contexts, where values are connected to each other within a practical whole. Whence Dreyfus: "it is a fundamental and strange characteristic of our lives that insofar as we turn our most personal concerns into objects, which we can study and choose, they no longer have a grip on us." ${ }^{103}$ This is not really so strange, however, because we all know (or at least should know) that the more abstract the value, the more distant it will be from our practical concerns, the things that really matter to us. A cursory reading of major speeches by the leaders of oppressed groups thus shows right away that the power of their eloquence derives not from their disinterestedness, but from how they articulate values in particularistic rather than abstract terms. Think of Louis Riel's final statement at his treason trial in Regina, 1885; of Theodor Herzl's address to the First Zionist Congress in Basel, 1897; of Martin Luther King Jr.'s "I Have A Dream" speech at the Lincoln Memorial in Washington, 1963; or of Nelson Mandela's "I Am

\footnotetext{
102 Berlin, "Herzen and His Memoirs," in Against the Current, p. 246.

${ }^{103}$ Dreyfus, What Computers Still Can't Do: A Critique of Artificial Intelligence (Cambridge, MA: MIT Press, 1992, 3rd ed.), p. 275. See also Kierkegaard, “The Present Age,” esp. p. 92.
} 
Prepared to Die" statement from the dock in front of the Pretoria Supreme Court, $1964 .{ }^{104}$ In each case, these leaders expressed agendas for action that took full account of the practical realities.

Perhaps one reason why pluralists, with their often tragic view of politics, end up relegating the isolated cores of values to the "darkness and void" is that otherwise the values risk becoming comic. In fact, there exists a whole genre of dramatic comedy based around what E.M. Forster has called "flat" characters, those which are dominated by a lone quality of mind or mood - what Ben Jonson, in keeping with the Renaissance psychology of his time, labelled a "humour." 105 Such dominance produces an exaggeration effect which makes the character into a caricature that we find funny. However, instead of welcoming this as the basis of a form of moral or political satire (one that highlights the need to transform the value in question so that it may be reconciled with others), pluralists maintain their belief in the static purity of a value's core. As a result, they limit any change to the tragic compromising of negotiation and, in consequence, they end up with a politics that remains all too serious.

\section{IV}

A political philosophy that favours reconciliation over the application of a systematic theory of justice, and over the struggle for balanced accommodation, is one that offers a path between the extremes of monism and pluralism. It calls on citizens to put their common good first by responding to conflicts with conversation. Because when a conversation succeeds, it brings both integration, hence progress towards unity, and the kind of shared understandings that respects difference and so diversity. ${ }^{106}$ When successful, this approach can be said to move us "towards One, as many," something that's only possible within a holistic - but disunified - practical context. At the same time, the practical shouldn't be considered so alien from the aesthetic that we fail to see the presence within the former of aesthetic structural forms such as comedy and tragedy.

\footnotetext{
${ }^{104}$ See Riel, “Final Trial Statement,” Herzl, “First Congress Address,” King, Jr., “I Have A Dream,” and Mandela, "I Am Prepared to Die."

105 See Forster, Aspects of the Novel (London: Penguin, 2005 [1927]), pp. 73-81; and Jonson, Every Man out of His Humour, ed. Helen Ostovich (Manchester: Manchester University Press, 2001 [1599]). Not that such characters are to be found only in comedies. See, for example, Stephan Zweig, Beware of Pity, trans. Phyllis and Trevor Blewitt (New York: New York Review Books, 2006).

106 For "understanding," Gadamer has written, "is always understanding-differently." Gadamer, "Letter to Dallmayr," in Diane P. Michelfelder and Richard E. Palmer, eds., Dialogue and Deconstruction: The GadamerDerrida Encounter (Albany: SUNY Press, 1989), p. 96.
} 
Likewise, the internal ends of the aesthetic dimension can be indirectly connected to other, practical ones situated outside it.

Still, we must never forget that these two dimensions are not only irreducible but also, on occasion, incompatible. Sometimes, no more than a permeable border lies between them; but sometimes, it is an abyss. Evidently, I want to see if there are occasions when we can close it. This makes the approach I am recommending different from not only pluralists, but also those who emphasize how the abyss must forever "flash" in and out of existence.

I'm thinking of those difference philosophers who are best understood as advocating, not movement towards unity, but rather a paradoxical affirmation of both the One and the Many, together. ${ }^{107}$ Often, they begin with the observation that the logic of monism (or "metaphysics") leads it to expand "the game" beyond all limits. One response, that of Jean-François Lyotard, is to express incredulity towards the very idea of such a single "metanarrative" and to affirm, alongside this alternative metanarrative of incredulity, a plurality of (language) games. ${ }^{108}$ Chantal Mouffe, for her part, advocates an agonistic democracy which assumes a consensus over certain ethicopolitical principles while acknowledging that these same principles exist through a multiplicity of diverging interpretations of them. This "conflictual consensus," she says, should be considered a "mixed-game," since it is partly collaborative and partly conflictual. ${ }^{109}$ By contrast, to Jacques Derrida "play is always lost when it seeks salvation in games," which is why he favours a deconstruction that would make way for an originary "freeplay" instead, one that both accepts the

107 Should they be interested in a slogan, they could do worse than Gilles Deleuze and Félix Guattari's "magic formula," namely "PLURALISM = MONISM." A Thousand Plateaus: Capitalism and Schizophrenia, trans. Brian Massumi (Minnesota: University of Minnesota Press, 1987), p. 20. For more, see my "Loving Wisdom," in Patriotic Elaborations, pp. 237-43.

108 See Lyotard, The Postmodern Condition: A Report on Knowledge, trans. Geoff Bennington and Brian Massumi (Minneapolis: University of Minnesota Press, 1984), esp. § 3; and Lyotard and Jean-Loup Thébaud, Just Gaming, trans. Wlad Godzich (Minneapolis: University of Minnesota Press, 1985), esp. p. 59 where Lyotard declares in favour of a paganism which asserts "a multiplicity of small narratives. And from that, 'one ought to be pagan' means 'one must maximize as much as possible the multiplication of small narratives'." Notice how the prescription applies uniformly to the multiplicity, unifying it. See also the questions Lyotard poses on pp. 94-96 as well as his concluding declaration, on p. 100, on behalf of "the justice of multiplicity: it is assured, paradoxically enough, by a prescriptive of universal value. It prescribes the observance of the singular justice of each game." As Sam Weber succinctly articulates this paradox: "one is dominating the other games in order to protect them from domination." Weber, "Afterward: Literature - Just Making It," in ibid., p. 105.

${ }^{109}$ Mouffe, “Deliberative Democracy or Agonistic Pluralism?” Social Research 66, no. 3 (Fall 1999): 745-58, p. 756; see also her On the Political (New York: Routledge, 2005), p. 33. 
constraints of "presence," such as the structures constituted by a game's rules, and disrupts them. ${ }^{110}$ Yet this amounts to more or less the same thing: an ironic attitude of the kind upheld by those who, as Richard Rorty recommends, are "never quite able to take themselves seriously." "111 Note the "quite" here, which establishes the sort of ambiguity that comes from recognizing something as being not so much a matter of degree as all-or-nothing - and yet also, somehow, both.

What we have here, I suggest, is very much like the "attitude of throwing off constraint" that characterizes those forms of play beloved of children and improvisational performers. ${ }^{112}$ But if its universalization leads you to contend, like the melancholy Jaques, that "all the world's a stage, and all the men and women merely players," 113 then I will object. Because we are more than just players, and to claim otherwise is to contribute, perhaps even more so than Rawls, to the aestheticization of our lives. There's a reason why "play" has been central to aesthetics since at least Kant and Schiller, and it suggests that the very same disinterested stance required for appreciating beauty for its own sake is also involved in playing according to rules for their own sake, that is, in playing games. But as numerous social critics have complained, aestheticization has already gone far enough. ${ }^{114}$ To which I would add that we need to see how it is accompanied by a kind of "Gnostic threat": by refusing the seriousness of life, we are led to view the whole world as unreal. And when that happens, then, as the nihilist saying goes, anything is possible.

110 Derrida, "Plato's Pharmacy," in Dissemination, trans. Barbara Johnson (Chicago: University of Chicago Press, 1981), p. 158; Derrida, "Structure, Sign and Play in the Discourse of the Human Sciences," in Writing and Difference, trans. Alan Bass (Chicago: University of Chicago Press, 1978), pp. 278, 294. In contrast to Richard J. Bernstein, I would characterize Derrida's approach as a form of "semi-serious play." See Bernstein, "Serious Play: The EthicalPolitical Horizon of Derrida," in The New Constellation: The Ethical-Political Horizons of Modernity/Postmodernity (Cambridge, MA: MIT Press, 1991). Game theorists are among those who assume that we're engaged in strictly serious play.

${ }^{111}$ Rorty, Contingency, Irony, Solidarity (Cambridge: Cambridge University Press, 1989), p. 73.

112 Susanna Millar, The Psychology of Play (Harmondsworth: Penguin, 1968), p. 21; and see Keith Johnstone, Impro: Improvisation and the Theatre (New York: Routledge, 1979). Incidentally, Johnstone is the originator of Theatresports, a competitive form of improvisational theatre whose participants can be considered "players" in two senses. See Johnstone, Impro for Storytellers (New York: Routledge, 1999), ch. 1.

${ }_{113}$ As You Like It, II.vii.138-39; see also The Merchant of Venice, I.i.77-78. Others who can be said to endorse this claim, albeit in very different ways, include D.W. Winnicott, Playing and Reality (New York: Basic Books, 1971); James S. Hans, The Play of the World (Amherst: University of Massachusetts Press, 1981); James P. Carse, Finite and Infinite Games: A Vision of Life as Play and Possibility (New York: Random House, 1997); and James E. Combs, Play World: The Emergence of the Ludenic Age (Westport, CN: Praeger, 2000).

${ }^{114}$ See, for example, Guy Dabord, The Society of the Spectacle, trans. Donald Nicholson-Smith (New York: Zone Books, 1995 [1967]); and Neil Postman, Amusing Ourselves to Death: Public Discourse in the Age of Show Business (New York: Penguin, 1986). Films that have taken up this theme include Sidney Lumet's Network (1986) and Denys Arcand's Days of Darkness (2007). 
Perhaps I'm overstating the danger. We can be sure of one thing, however: conversation is incompatible with such widespread aestheticization. Because conversation requires earnest interlocutors, the kind that take their exchanges seriously. Yet the obstacles to conversing are many and real, which is why those of us who would give it a place in politics need to recognize how frequently it will fail, leaving negotiation as the next best option. This means that politics will indeed often have to be a tragic, rather than comic, affair. Still, at least we may be said to have given both tragedy and comedy their due, and so to have taken politics with just the right amount of seriousness. 